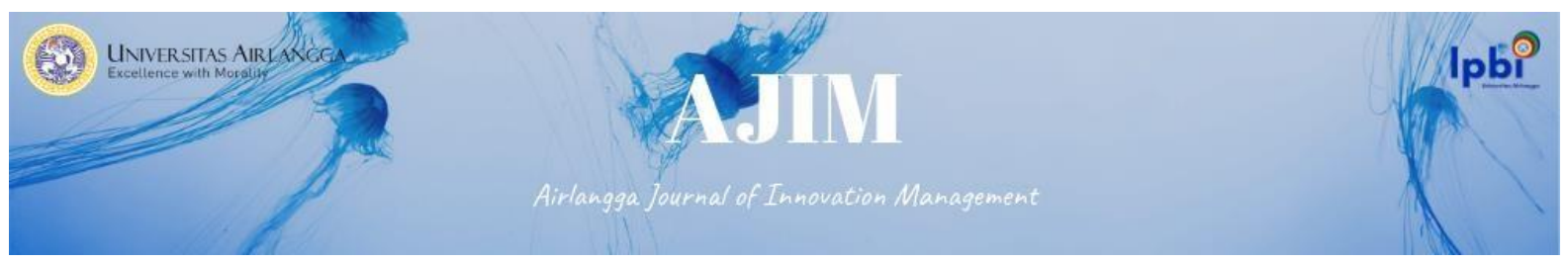

Vol. 2 No.1 Juni 2021

e-ISSN: 2722-5062

DOI : 10.20473/ajim.vvii.26541

\title{
ENTREPRENEURSHIP SELF-EFFICACY, ATTITUDES TOWARDS ENTREPRENEURSHIP, AND STUDENT'S ENTREPRENEURSHIP INTEREST
}

\author{
Dismas Persada Dewangga Pramudita \\ Universitas Atma Jaya Yogyakarta \\ e-mail: dismas.persada@uajy.ac.id
}

\begin{abstract}
One of the causes of large number unemployement is an imbalance between number of jobs and number of job applicants. Total population of Indonesia in September 2020 has reached 270 million (BPS, 2021). The Central Statistics noted that there are quite a large number of unemployed college graduates (BPS, 2020). Increasing number of entrepreneurs is considered to be one of solutions to reduce unemployment. This study aims to determine an effect of entrepreneurial self-efficacy on entrepreneurial intention directly or through attitudes towards entrepreneurship. This research was conducted at a private university in Yogyakarta with Informatics Engineering student respondents. Research data processing was carried out by Partial Least Square 3 software. The results of this study indicate that entrepreneurial self-efficacy has a direct and positive effect on entrepreneurial intention. Then, attitudes towards entrepreneurship have been shown to play a role as a mediator in relationship between entrepreneurial self-efficacy and entrepreneurial intention. Based on these results, mediating role of attitudes towards entrepreneurship is partial mediation. The results of this study are expected to be useful to encourage higher education institutions and government to motivate younger generation, especially Informatics Engineering students, to have an entrepreneurial spirit and have a positive attitude towards entrepreneurial behavior so that they are interested in becoming entrepreneurs. Informatics Engineering students are expected to be able to support economic recovery due to Covid19 pandemic through works in form of software.
\end{abstract}

\section{Keywords: Self-Efficacy, Entrepreneurship, Personality, Behavior}

\section{Introduction.}

The high number of unemployment rate is a main problem that is in field of employment in Indonesia. The classic problem that must be faced by this country is about an availability of job opportunities which is still not balanced with number of job seekers. Indonesia government has made efforts to expand job opportunities, including infrastructure development, for example construction of toll roads and various other projects. The results of population census calculation in September 2021 noted that total population of Indonesia has reached 270 million people (BPS, 2021). This high population in country will certainly impacts on high level of job competition. 

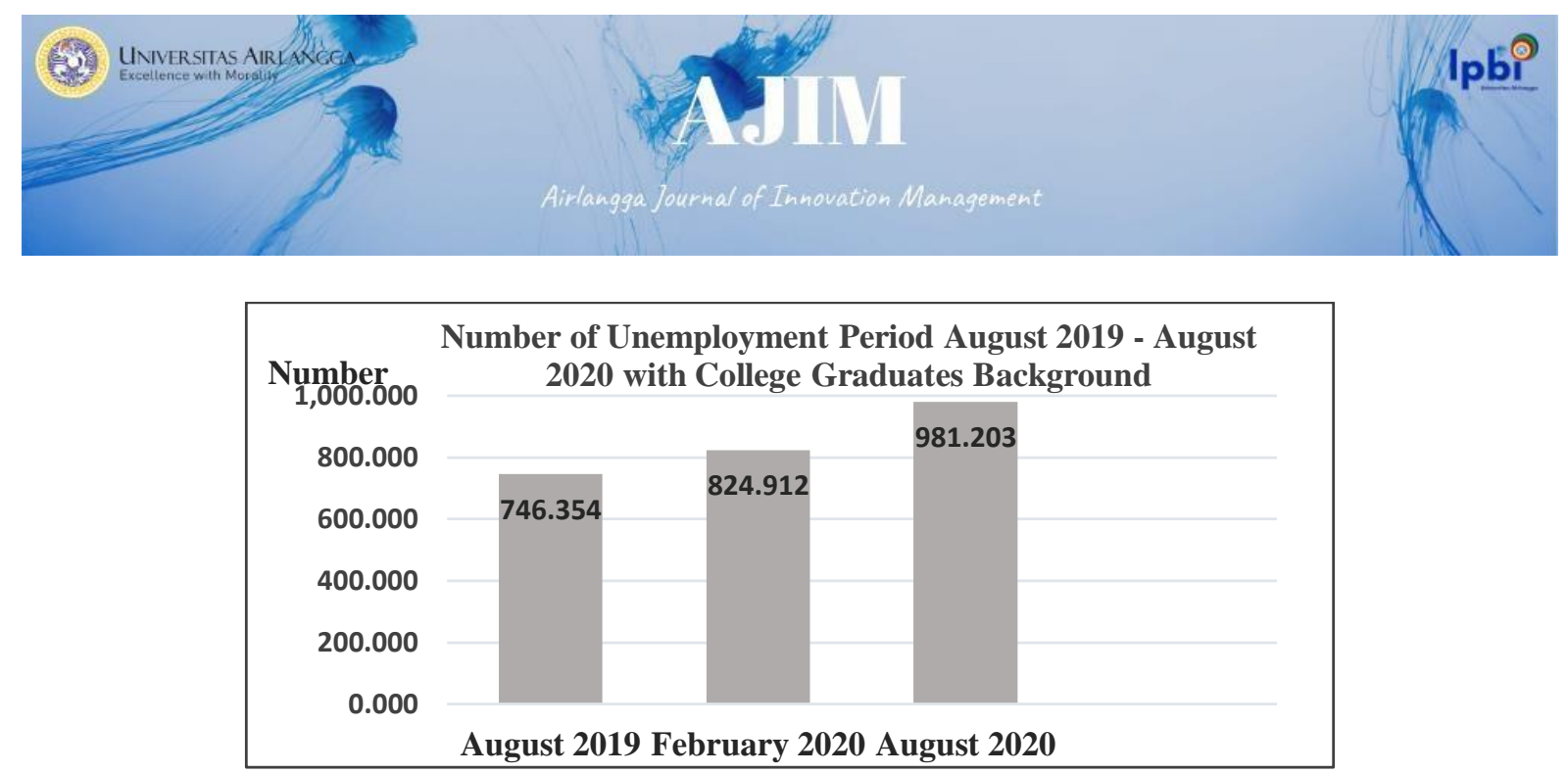

Source: Badan Pusat Statistik (2020), edited

\section{Figure 1.1 Graph of Unemployment for the Period August 2019-August 2020 with College Graduates Background}

At least every semester, students from various universities graduate. Each graduation period, of course, graduates a large number of students. As educated people, workforce who have a higher education background are expected to be able to get decent jobs and in accordance with fields they have studied. However, ironically, there are still many university graduates who are currently unable to find work. Data that has been collected and processed by Central Statistics Agency (BPS) shows that there are quite a large number of unemployed college graduates (BPS, 2020). During August 2019 to August 2020 , there was an increase in number of university graduates who had not yet found a job or in other words become unemployment (BPS, 2020). This situation shows that having an educational background of at least a bachelor's degree (S1) does not guarantee that fresh graduates can get jobs easily and in accordance with their expertise fields. The number of college graduates should be a solution in order to reduce unemployment rate.

Corona Virus Disease 2019 (Covid-19) pandemic has brought negative impact on various sectors in Indonesia, including economic sector. Entrepreneurship is expected to be an alternative solution to recover economic impact. Increasing a number of entrepreneurs requires role of community together with government, private sector and many supports from universities. Educational institutions, especially universities, are expected to participate in increasing number of future Indonesian entrepreneurs. Universities as academic institutions are expected to play a role in fostering positive attitude towards entrepreneurship among students so that later they are interested in becoming entrepreneurs (Fayolle \& Liñán, 2014).

Government through its role as a policy maker can influence growth number of entrepreneurs. Gelard and Saleh (2011) research has proven that regulations issued by the government are able to influence interest in becoming entrepreneurs. These regulations can be implemented through tax breaks and ease of licensing for prospective entrepreneurs whom just started their business. Entrepreneurship Global Index (2018) notes that number Indonesia entrepreneurs is still very small compared to neighboring countries such as Malaysia (6 percent), Thailand (5 percent) and Singapore (7 percent). Based on these conditions, entrepreneurial spirit in Indonesia needs to be instilled from an early age, especially in younger generation of Indonesia (KOMINFO, 2020).

Internal factors related to personal character are considered as potential to influence entrepreneurial interest (Sánchez, 2011). In his research, Sánchez (2011) measures self-efficacy as a personality dimension of an entrepreneur. Self-efficacy is a level of individual belief in ability and skills to be successful in doing certain things (Bandura, 1977). Self-efficacy studied in this study focuses on entrepreneurial self-efficacy. Internal factors in form of individual perceptions of three motivational 


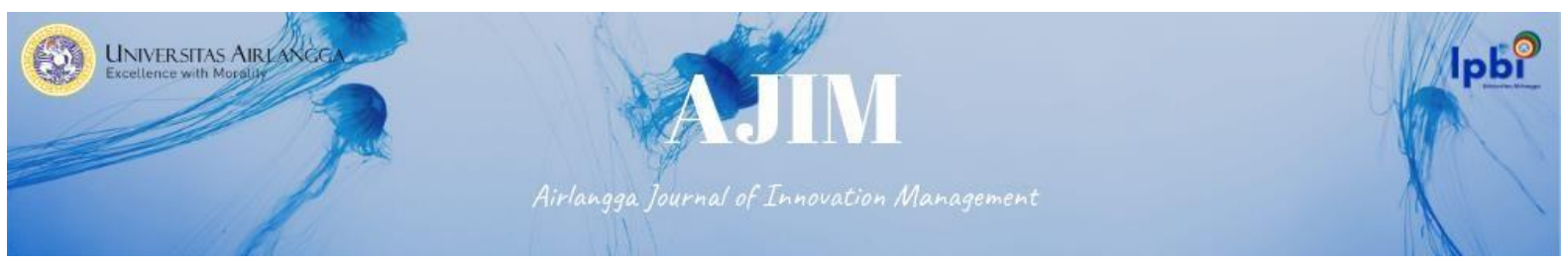

factors in Theory of Planned Behavior also play a role in influencing interest in entrepreneurship (Ajzen, 1991). The three factors are: attitudes towards behavior, subjective norms, and behavioral control. In this study, researchers focused on one of motivational factors, namely attitudes towards entrepreneurial behavior.

Covid-19 pandemic that is currently engulfing Indonesia has transform the way of interaction between individuals. Before Covid-19 pandemic, people were still free to gather and hold meetings offline. After Covid-19 pandemic hit, majority of meetings were held online. The smooth running of meetings, discussions, and online meetings depends on digital technology-based services, namely a variety of online meeting software. In addition to software for online meetings, various public services have been moved to publish software that makes it easier to manage various administrative matters, such as managing an online driving license renewal through an application. Online application-based services can only be developed with special skills in field of Information Engineering.

Creating and developing a software application or public service software, opening an Information Technology consultant service is a form of business opportunity for Informatics Engineering graduates. The increase in number of Indonesian entrepreneurs is expected to play a role in reducing number of unemployment. Based on explanation that has been described above, researcher aims to find out whether personality factors in form of entrepreneurial self-efficacy can directly influence the entrepreneurial interest of Informatics Engineering students or not. In addition, level of individual interest reflected in attitudes towards entrepreneurship will also be investigated whether it acts as a mediator between entrepreneurial self-efficacy and entrepreneurial interest or not.

\section{Literature Review}

This study uses several theories as a basis that supports explanation and analysis of discussion about relationship between variables studied.

\section{Definition of Entrepreneurial Self-Efficacy}

Self-efficacy is one of dimensions of entrepreneur personality (Sánchez, 2011). Individuals with a high level of self-efficacy are able to carry out various activities in order to build and develop new businesses because they are not burdened by doubts regarding their abilities (Trevelyan, 2009). Entrepreneurial self-efficacy is an individual's belief in his ability to be able to do various things related to entrepreneurial activities (Blasco et al., 2018). Barnir et al. (2011) argues that entrepreneurial selfefficacy is "a perception of one's ability to successfully perform tasks and roles of an entrepreneur and face various consequences of creating a business". Entrepreneurial self-efficacy is a person's confidence in his ability to engage in entrepreneurial activities (Tsai et al., 2016).

\section{Entrepreneurial Self-Efficacy Dimension}

According to (De Noble et al., 1999), there are six types of skill dimensions that can be used to measure entrepreneurial self-efficacy, namely:

1. Risk and uncertainty management skills

2. Skills related to product development and innovation

3. Skills in managing relationships with other people related to business networks

4. Ability to find business opportunities

5. Procurement and allocation of matters related to important resources

6. Development and maintenance of an environment that supports innovation. 


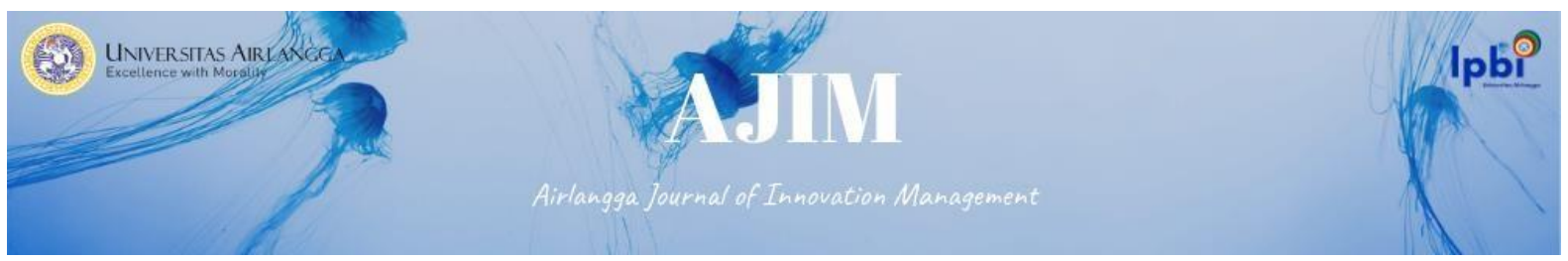

A previous study by Liñán (2008) analyzed relationship between entrepreneurial skills and three motivational factors the Theory of Planned Behavior. The three factors are: attitudes towards behavior, subjective norms, and behavioral control (Ajzen, 1991). In this study, researchers focused on one of motivational factors, namely attitudes towards entrepreneurial behavior. Liñán (2008) defines entrepreneurial skills as perception of confidence in having a specific skill level related to entrepreneurship. Referring to a previous study by Liñán (2008), entrepreneurial skills were measured by adapting indicators from the research of De Noble et al. (1999) which consists of six statements. Based on this explanation, researcher concludes that entrepreneurial skills concept in Liñán's (2008) research has an identical meaning to entrepreneurial self-efficacy.

\section{Attitude towards Entrepreneurship \\ Definition of Attitude towards Entrepreneurship}

Attitude towards entrepreneurial behavior is one of motivational factors in Theory of Planned Behavior that affects one's entrepreneurial interest. Attitude towards a behavior can be explained as an extent to which a person has a positive or negative personal assessment of a behavior (Ajzen, 1991). Attitude towards entrepreneurship is one of important factors that shape a person's desire to start a career as an entrepreneur (Kautonen et al., 2013). Universities as academic institutions have a potential to foster a positive attitude towards entrepreneurship among students so that they can be interested in becoming entrepreneurs (Fayolle \& Liñán, 2014). Attitude towards entrepreneurship is a form of positive and negative evaluation of a person about specific behaviors related to entrepreneurial activity (Tsai et al., 2016). Attitude towards entrepreneurship refers to difference between concepts of desire to become an entrepreneur or desire to work as an employee (Souitaris et al., 2007).

\section{Attitude-Forming Factors against Entrepreneurship}

Study of Liñán (2008) also prove that attitudes towards entrepreneurship are positively influenced by entrepreneurial self-efficacy. The results of Liñán's (2008) research can be interpreted that a person's high level of confidence regarding skills in entrepreneurship is proven to be able to form positive perceptions of entrepreneurial activities.

\section{Entrepreneurial Interest}

\section{Definition of Interest in Entrepreneurship}

Interest in entrepreneurship can be interpreted as a mental orientation related to desires and expectations that encourage someone to choose a career as an entrepreneur (Guerrero et al., 2008). Interest in entrepreneurship is a belief in a person regarding intention to set up a business and consciously planning to do so in future (Thompson, 2009). Interest in entrepreneurship can also be interpreted as a person's interest in setting up a business, owning a business or developing an existing business (Palamida, 2016). Interest in entrepreneurship can also be considered as a phenomenon when an individual makes a decision to start a business (Blasco et al., 2018).

\section{Factors Affecting Interest in Entrepreneurship}

Interest in entrepreneurship is generally influenced by various factors. According to Liñán et al. (2011), there are three main categories of factors that have most influence on interest in entrepreneurship, namely: motivational factors, environmental factors (contextual), and demographic factors related to individual backgrounds. According to Theory of Planned Behavior (Ajzen, 1991), there are three motivational factors that influence a person's interest in entrepreneurship, namely: attitudes towards behavior, subjective norms, and behavioral control. According to Gelard and Saleh 


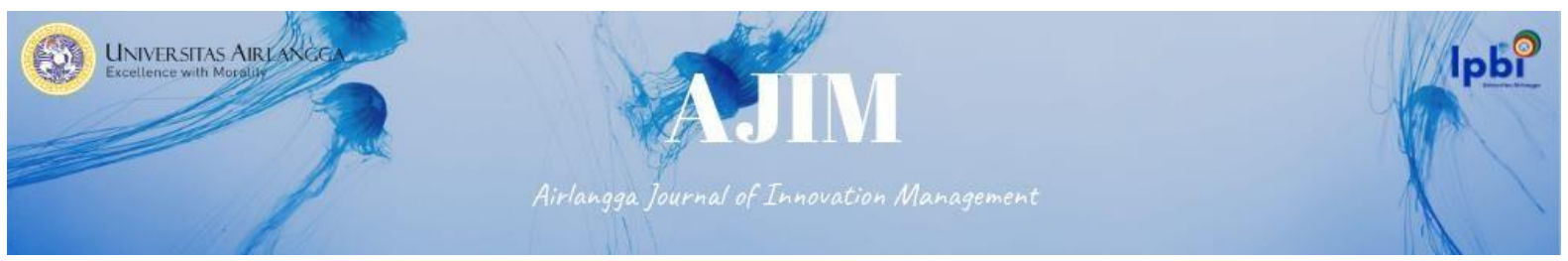

(2011), there are four contextual environmental factors that influence interest in entrepreneurship, namely: educational support, structural support, formal network, and informal network. Educational support in form of support by higher education institutions through training programs related to entrepreneurship. Structural support in form of government policies related to taxes, employment, and various matters related to support for entrepreneurship. Support in form of tax relief policies is the most common thing done to encourage the micro and medium business sector. Formal networks relate to support from government agencies, state-run financial institutions, lawyers, business consulting firms and insurance companies. Informal networks are related to support that comes from colleagues, friends, family members, and parents in form of moral and material support. Furthermore, demographic factors that also influence formation of interest in entrepreneurship are living environment, education level, gender, and age (Liñán et al., 2011).

\section{Relationship Between Variables}

\section{Entrepreneurial Self-Efficacy and Interest in Entrepreneurship}

Entrepreneurial self-efficacy is an individual's belief in their ability to carry out various activities related to entrepreneurship (Blasco et al., 2018). Individuals with a high level of entrepreneurial self-efficacy have a strong belief that they can come up with viable and useful ideas in order to develop new businesses (Wilson et al., 2007). Several previous researchers have proven that there is a significant positive effect on entrepreneurial self-efficacy on student entrepreneurship interest (Wilson et al., 2007).

\section{Entrepreneurial Self-Efficacy and Attitudes towards Entrepreneurship}

Results of Liñán (2008) prove that entrepreneurial self-efficacy has a positive effect on one's entrepreneurial interest. Entrepreneurial self-efficacy is a person's confidence regarding their capability to engage in entrepreneurial activities (Tsai et al., 2016). People with a high level of confidence in their skills for starting a business tend to expect that they will be able to set up and manage a successful business, and this expectation has potential to motivate their behavior related to entrepreneurship (Tsai et al., 2016). As previously discussed, entrepreneurial self-efficacy is an individual's belief in abilities that exist within them so that people are able to do various things related to entrepreneurial activities (Blasco et al., 2018). This belief has potential to shape a person to have a positive attitude towards entrepreneurship.

\section{Attitude towards Entrepreneurship and Interest in Entrepreneurship}

A positive attitude towards entrepreneurship has potential to form an interest in entrepreneurship. Research by Liñán (2008) proves that a person's interest or positive attitude towards entrepreneurship has a positive effect on interest in entrepreneurship. A high level of trust related to talents and abilities fosters a person's belief that they can start a business and can manage it so that business is successful (Shahab et al., 2019). This belief ultimately motivates and encourages their behavior and attitudes to be more interested in entrepreneurship. Having a positive attitude towards a series of entrepreneurial activities is expected to form a strong interest in entrepreneurship. The research of Shahab et al. (2019) also proves that there is a positive relationship between attitudes towards entrepreneurship and one's interest in entrepreneurship. 


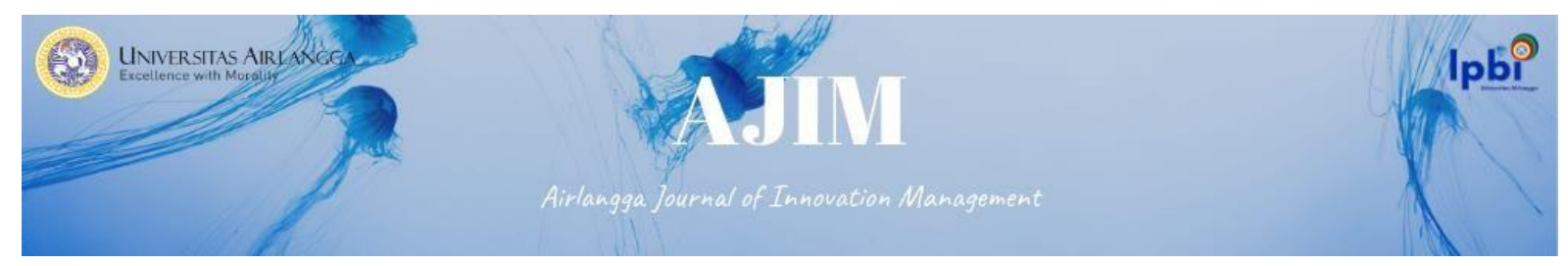

\section{Conceptual Framework and Hypothesis}



$\mathrm{H}_{1}$ : Entrepreneurship self-efficacy positively influence interest in entrepreneurship

$\mathrm{H}_{2}$ : Attitude towards entrepreneurship mediating positive influence between entrepreneurship self-efficacy positively and interest in entrepreneurship.

\section{Method}

\section{Research Approach}

This research uses a quantitative approach. Quantitative approach is used to examine entire relationship between research variables. The quantitative approach is a method used in process of observing certain populations or samples, through process of collecting data using research questionnaires which are then analyzed statistically to test research hypotheses that have been determined (Sugiyono, 2017:8).

\section{Variable Identification}

There are three variables that will be examined in this study. The three variables are as follows:

1. Independent variable $(\mathrm{X})$ : entrepreneurial self-efficacy

2. Mediator variable (Z): attitudes towards entrepreneurship

3. Dependent variable (Y): interest in entrepreneurship

\section{Operational Definition and Measurement of Variables}

Definition of each variable and method used to measure variables in this study are as follows. 


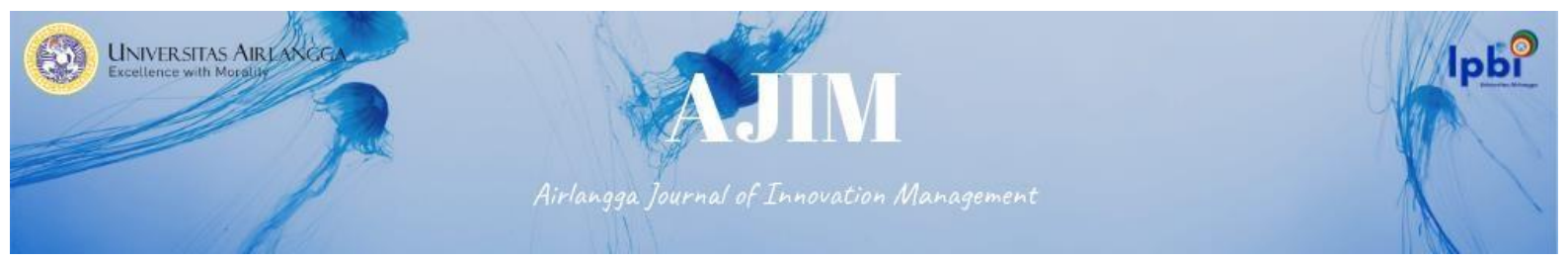

Table 1

Operational Definition and Variable Measurement

\begin{tabular}{|c|c|c|c|}
\hline Variable & $\begin{array}{l}\text { Operational } \\
\text { definition }\end{array}$ & Indicator items & Scale \\
\hline $\begin{array}{l}\text { Entrepreneurial } \\
\text { Self-Efficacy (X) }\end{array}$ & $\begin{array}{l}\text { Individual's } \\
\text { confidence in } \\
\text { abilities and skills } \\
\text { in carrying out } \\
\text { various processes } \\
\text { to start a business } \\
\text { (Liñán, 2008) }\end{array}$ & 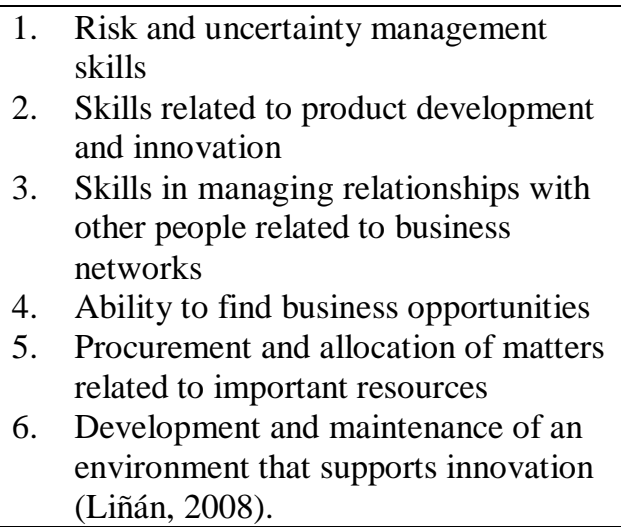 & $\begin{array}{l}\text { Likert scale with } 5 \\
\text { scales, from } 1 \text { to } 5 . \\
\text { 1. Strongly Disagree } \\
\text { 2. Disagree } \\
\text { 3. Hesitant } \\
\text { 4. Agree } \\
\text { 5. Strongly Agree }\end{array}$ \\
\hline $\begin{array}{l}\text { Attitudes towards } \\
\text { Entrepreneurship } \\
\text { (Z) }\end{array}$ & $\begin{array}{l}\text { Positive or } \\
\text { negative personal } \\
\text { assessment of the } \\
\text { process of starting } \\
\text { a business (Liñán } \\
\text { and Chen, 2009). }\end{array}$ & $\begin{array}{l}\text { 1. Interest in a career as an entrepreneur } \\
\text { 2. Desire to become entrepreneurship if } \\
\text { have opportunity and resources } \\
\text { 3. Interest in becoming an entrepreneur } \\
\text { compared to other options } \\
\text { 4. Expected level of satisfaction when } \\
\text { becoming an entrepreneur } \\
\text { 5. Personal assessment of advantages and } \\
\text { disadvantages of being an entrepreneur } \\
\text { (Liñán and Chen, 2009). }\end{array}$ & $\begin{array}{l}\text { Likert scale with } 5 \\
\text { scales, from } 1 \text { to } 5 . \\
\text { 1. Strongly Disagree } \\
\text { 2. Disagree } \\
\text { 3. Hesitant } \\
\text { 4. Agree } \\
\text { 5. Strongly Agree }\end{array}$ \\
\hline $\begin{array}{l}\text { Interest in } \\
\text { Entrepreneurship } \\
(\mathrm{Y})\end{array}$ & $\begin{array}{l}\text { Self-confidence } \\
\text { and } \\
\text { encouragement } \\
\text { related to the } \\
\text { intention to set up } \\
\text { a business and } \\
\text { consciously plan } \\
\text { to do so in the } \\
\text { future (Liñán, } \\
\text { 2008). }\end{array}$ & $\begin{array}{l}\text { 1. Have a professional goal to become } \\
\text { entrepreneur } \\
\text { 2. Willingness to make every effort to } \\
\text { start a business } \\
\text { 3. Determined to establish a company } \\
\text { in future } \\
\text { 4. Have confidence in intention to start } \\
\text { a business } \\
\text { 5. Have a strong intention to start a } \\
\text { business (Liñán, 2008). }\end{array}$ & $\begin{array}{l}\text { Likert scale with } 5 \\
\text { scales, from } 1 \text { to } 5 . \\
\text { 1. Strongly Disagree } \\
\text { 2. Disagree } \\
\text { 3. Hesitant } \\
\text { 4. Agree } \\
\text { 5. Strongly Agree }\end{array}$ \\
\hline
\end{tabular}

Source: Research process (2021)

\section{Data Types and Sources}

The type of data in this study is quantitative data. The source of data in this study is primary data. Primary data was obtained through a questionnaire distributed to students in semester 5 and 7 of Informatics Engineering program, Faculty of Science and Technology, University of Sanata Dharma (IE FST USD) in 2020/2021 academic year whom became this research object.

\section{Population and Sample}

Population in this study are students of Informatics Engineering FST USD semester 5 and 7 in 2020/2021 academic year who are not entrepreneurs or do not have businesses. In this study, sample used to collect data has provisions, namely: sample is an active student in semester 5 and 7 of Informatics Engineering FST USD even semester in 2020/2021 academic year who does not have a business or is not an entrepreneur. The reason for determining these criteria is because students in 


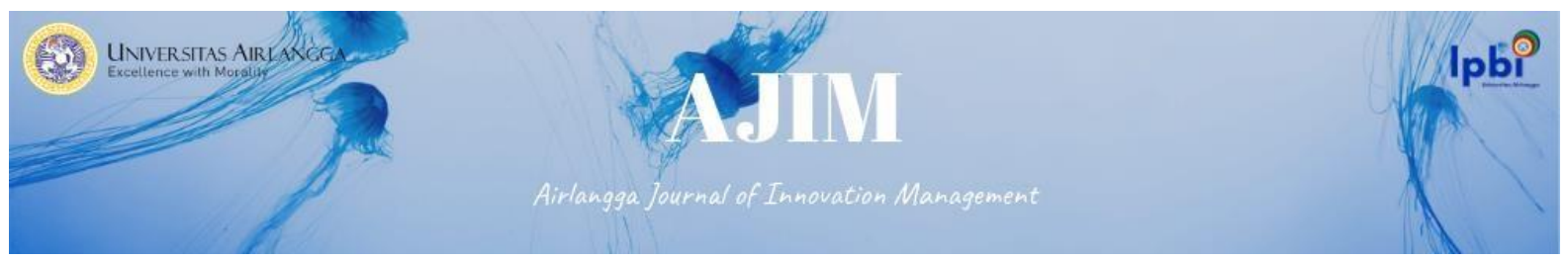

semesters 5 and 7 have taken more Informatics Engineering courses than students in semesters 1 and 3. Another consideration is that students in those semesters are relatively easy to coordinate. Sampling technique used in this study is non-probability sampling which does not provide equal opportunities for every member of population. This research used purposive sampling, namely determination of sample with certain considerations (Sugiyono, 2017). This technique is needed because not all students have a background that is closely related to entrepreneurial activity. In addition, due to time constraints, data collection using Google Forms may not be able to accommodate the entire population. By using this technique, 50 respondents were obtained consisting of 5 th and 7 th semester students.

\section{Analysis Techniques}

In data analysis technique, first step is to score for all variables. This study uses a Likert scale with five scales ranging from strongly disagree, disagree, undecided, agree, and strongly agree. Likert scale with five scales was used to measure variables of entrepreneurial self-efficacy, attitudes towards entrepreneurship, and interest in entrepreneurship through a questionnaire. For data analysis process, analytical tool used in this research is Partial Least Square (PLS) version 3.0. Partial Least Square is one of Structural Equation Modeling (SEM) methods. Processing with Partial Least Square allows data that are not normally distributed to be analyzed. Another reason that underlies a use of PLS is that it can analyze small samples in complex research models (Hair et al., 2014). Each indicator item in variables studied in this study is a reflective indicator which means that changes in latent construct will affect changes in indicators. Removing one indicator from measurement model (measurement model or outer model) does not change meaning of construct (Hair et al., 2014). In PLS technique, determination of outer model (measurement model) and inner model (structural model) are steps that must be carried out.

\section{Outer Model Evaluation}

In evaluating outer model process, researchers conducted several types of reliability tests and validity tests. The first step is to test validity of all indicator items. Testing validity of PLS technique consists of two types, namely construct convergent validity test and discriminant validity test. The research indicator item is declared to have passed convergent validity test if outer loading value is > 0.7. Construct is declared to have passed convergent validity test if it has an average variance extracted (AVE) of $>0.5$.

The next step is to test discriminant validity. The discriminant validity test can be done by comparing cross loading value of each indicator to its construct and cross loading value of each indicator to other constructs (Henseler et al., 2009). If cross loading value of each indicator on its construct is greater than other constructs value, then variable or construct has good discriminant validity. After validity test process is complete, it is continued with reliability test. To test reliability of all variable indicator (constructs), composite reliability test was carried out.

\section{Inner Model Evaluation}

The evaluation of inner model or structural model aims to predict causal relationship between hypothesized variables in research model (Hair et al., 2014). In PLS technique, quality assessment of model is based on its ability to predict endogenous variables. There are several criteria that can be used to assess model quality, namely: Coefficient of determination (R2), goodness of fit, and path coefficients. 


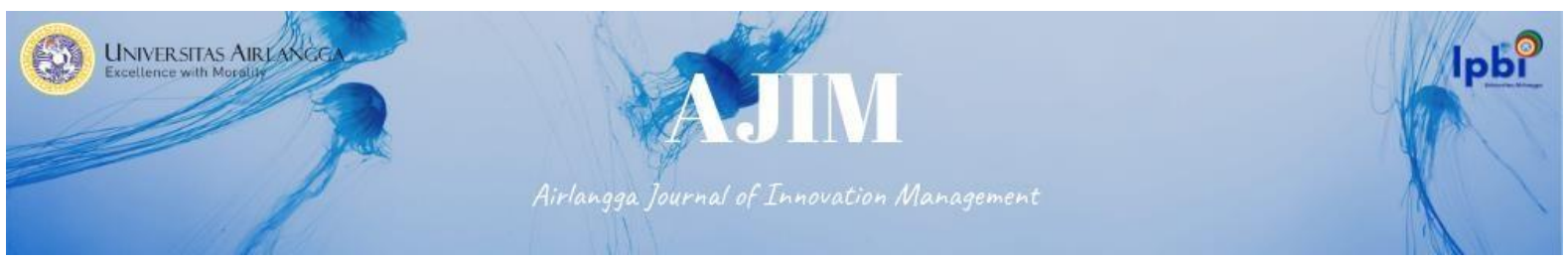

\section{Result And Discussion \\ Outer Model Test}

There are four types of tests that need to be carried out to test outer model, namely: convergent validity, construct validity, discriminant validity, and composite reliability.

\section{Convergent Validity Test}

Indicator item on each variable or construct is declared to have passed convergent validity test if it has a loading factor value greater than 0.7 (Hair et al., 2014).

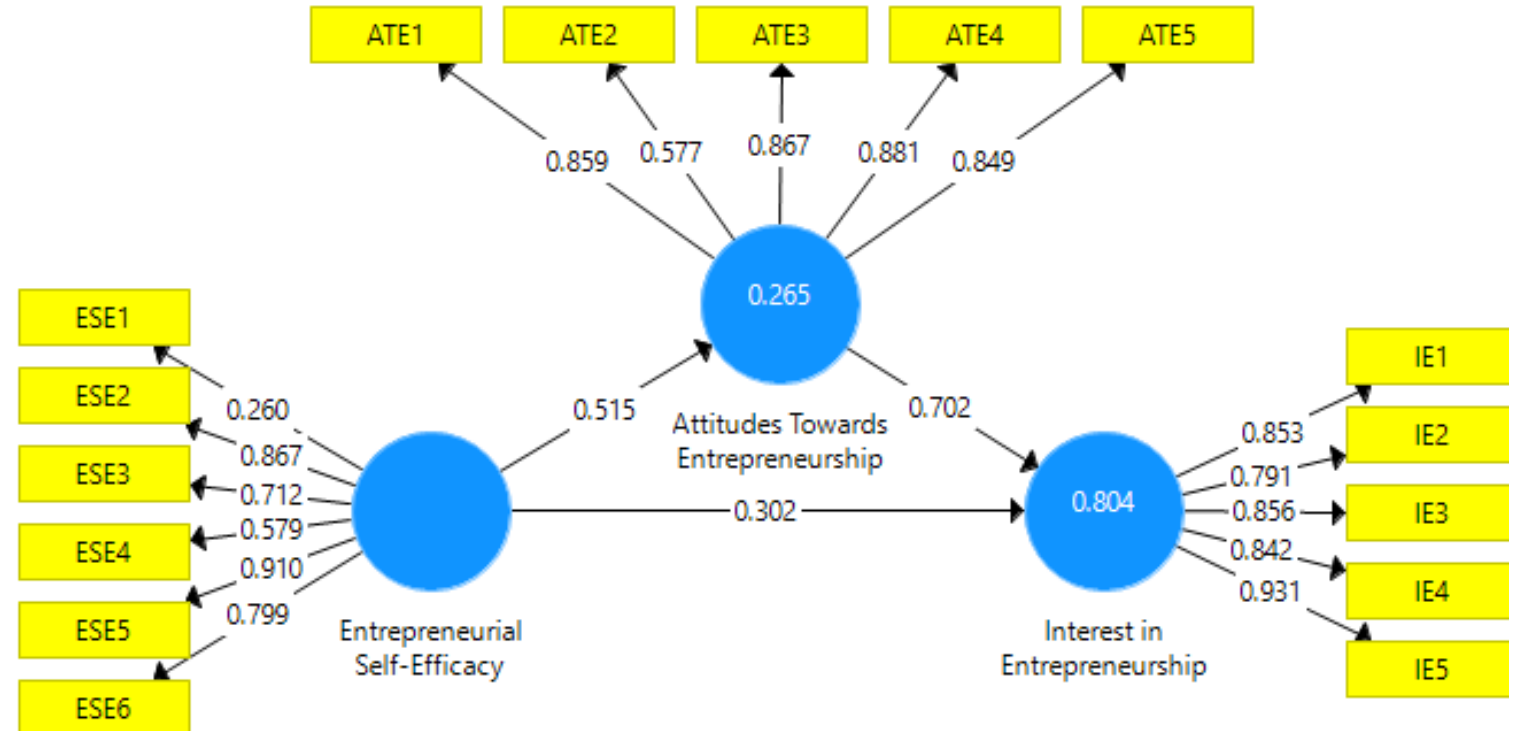

Figure 4.1 PLS Model Outer Path Diagram

Source: Results of research data processing with PLS version 3

Based on path diagram of outer model test results in Figure 4.1 above, it turns out that indicator items ESE1, ESE4, and ATE2 did not pass convergent validity test. Indicator items with a loading factor value of $<0.7$ must be excluded from research model because they are invalid. As impact of this, next step is to repeat outer model test process without involving the ESE1, ESE4, and ATE2 indicators.

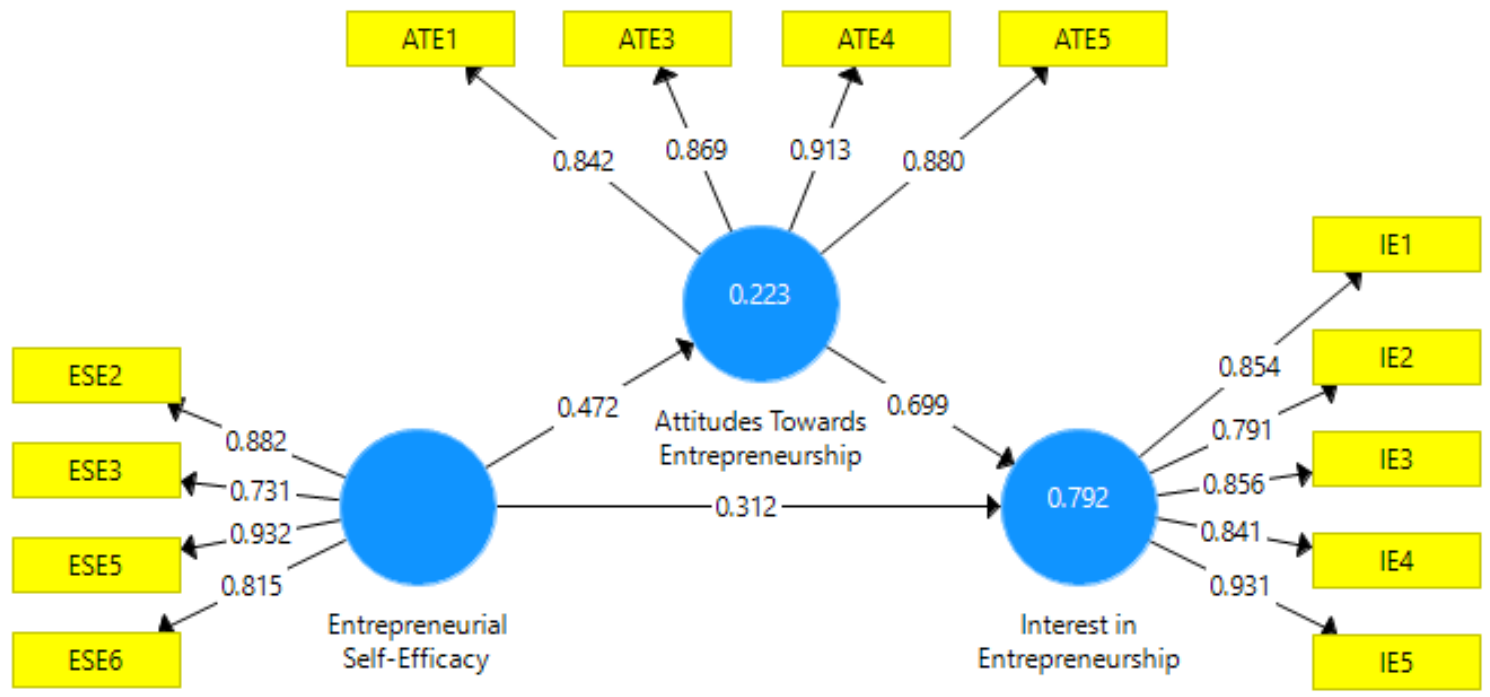

Figure 4.2 PLS Model Outer Path Diagram (revised)

Source: Results of research data processing with PLS version 3 


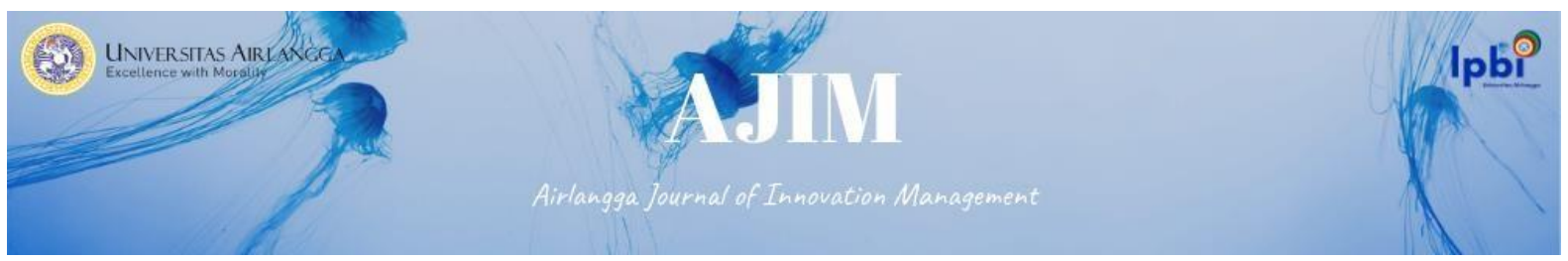

Figure 4.2 above shows that the loading factor for each indicator has a value higher than 0.7 so that it is proven to be a statistically valid measuring tool and is feasible to be used in research.

\section{Discriminant Validity Test}

The discriminant validity test is intended to test extent to which a variable is empirically different from one another (Hair et al., 2014). Two concepts that are conceptually different must show a clear and adequate difference. A variable or construct has good discriminant validity if loading value of a set of indicators on variable is higher than for other variables. This can be measured by comparing the cross-loading of each indicator.

Table 4.1

Cross Loading

\begin{tabular}{|c|c|c|c|}
\hline Indicator & ESE & IE & ATE \\
\hline ESE 2 & $\mathbf{0 . 8 8 2}$ & 0.521 & 0.389 \\
\hline ESE 3 & $\mathbf{0 . 7 3 1}$ & 0.422 & 0.343 \\
\hline ESE 5 & $\mathbf{0 . 9 3 2}$ & 0.563 & 0.383 \\
\hline ESE 6 & $\mathbf{0 . 8 1 5}$ & 0.626 & 0.460 \\
\hline IE 1 & 0.497 & $\mathbf{0 . 8 5 4}$ & 0.723 \\
\hline IE 2 & 0.481 & $\mathbf{0 . 7 9 1}$ & 0.707 \\
\hline IE 3 & 0.465 & $\mathbf{0 . 8 5 6}$ & 0.670 \\
\hline IE 4 & 0.663 & $\mathbf{0 . 8 4 1}$ & 0.697 \\
\hline IE 5 & 0.621 & $\mathbf{0 . 9 3 1}$ & 0.814 \\
\hline ATE 1 & 0.418 & 0.784 & $\mathbf{0 . 8 4 2}$ \\
\hline ATE 3 & 0.332 & 0.696 & $\mathbf{0 . 8 6 9}$ \\
\hline ATE 4 & 0.459 & 0.730 & $\mathbf{0 . 9 1 3}$ \\
\hline ATE 5 & 0.436 & 0.749 & $\mathbf{0 . 8 8 0}$ \\
\hline
\end{tabular}

Source: Results of data processing with PLS 3

\section{Construct Validity and Reliability Test}

A variable is considered to have good construct validity if Average Variance Extracted (AVE) value is higher than 0.5 . Then construct reliability is considered as good if value of composite reliability and Cronbach's alpha $>0.7$ (Hair et al., 2014). Following is output table of construct validity test results with AVE method and results of testing composite reliability and Cronbach's alpha:

Table 4.2

Construct Reliability and Validity

\begin{tabular}{|l|c|c|c|c|c|}
\hline \multicolumn{1}{|c|}{ Variable } & $\begin{array}{c}\text { Cronbach's } \\
\text { Alpha }\end{array}$ & $\begin{array}{c}\text { Composite } \\
\text { Reliabiliy }\end{array}$ & $\begin{array}{c}\text { Reliable / } \\
\text { Not Reliable }\end{array}$ & AVE & $\begin{array}{c}\text { Valid / } \\
\text { Not Valid }\end{array}$ \\
\hline Entrepreneurship Self Efficacy & 0.863 & 0.907 & Reliable & 0.712 & Valid \\
\hline Interest in Entrepreneurship & 0.908 & 0.932 & Reliable & 0.732 & Valid \\
\hline Attitudes in Entrepreneurship & 0.899 & 0.930 & Reliable & 0.768 & Valid \\
\hline
\end{tabular}

Source: Results of data processing with PLS 3 


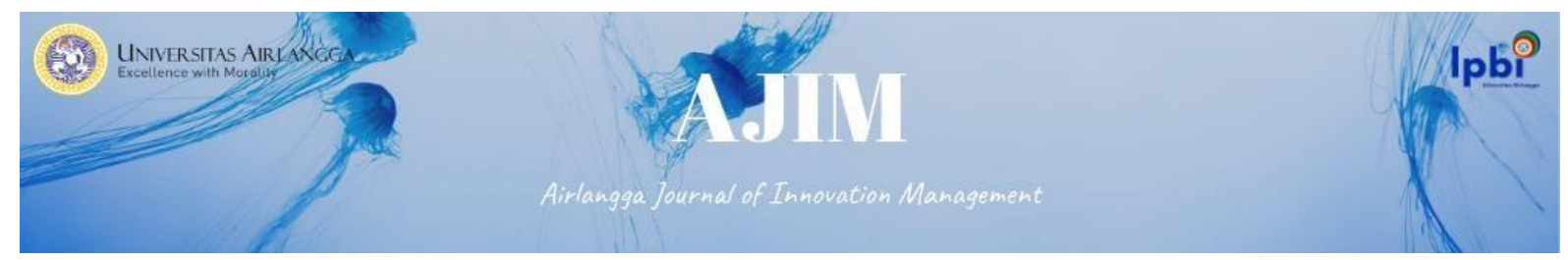

\section{Inner Model Test}

The inner model test or also called as structural model aims to predict a causality relationship between hypothesized variables in research model (Hair et al., 2014).

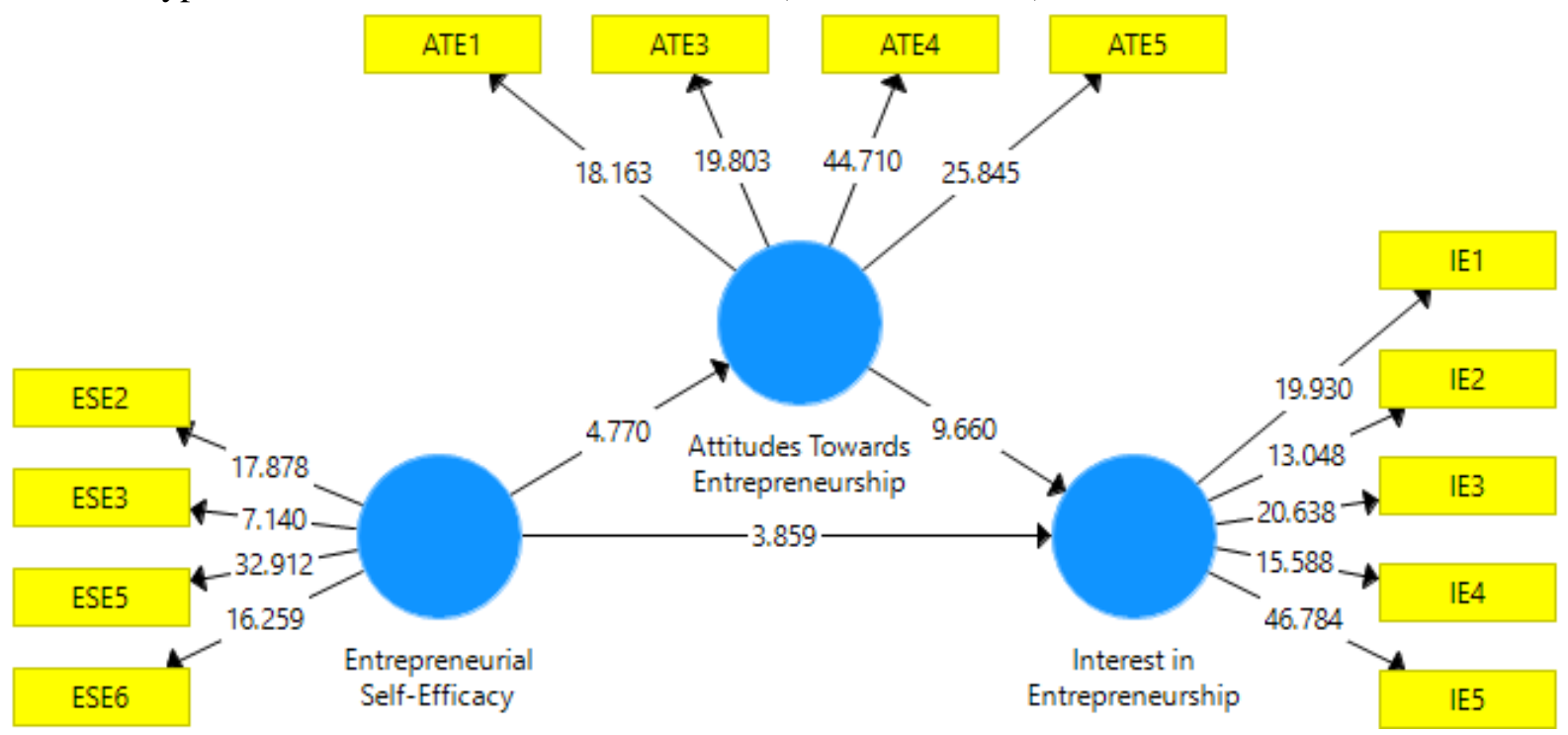

Figure 4.3 Inner Path Diagram PLS Model

Source: Results of research data processing with PLS version 3

By performing bootstrapping technique on PLS, significance level of statistical T test value for relationship between variables is obtained, as shown in Figure 4.3 above. In this study, relationship between latent variables is significant if value is $>1.64$. Because, in this study, researchers used a onesided T-statistical test.

Table 4.3

Path Coefficients (T-Statistics)

\begin{tabular}{|l|r|l|}
\hline & T-Statistics & \multicolumn{1}{|c|}{ Result } \\
\hline Entrepreneurial Self Efficacy $\rightarrow$ Interest in Entrepreneurship & 3,859 & Significant \\
\hline Entrepreneurial Self Efficacy $\rightarrow$ Attitudes Towards Entrepreneurship & 4,770 & Significant \\
\hline Attitudes Towards Entrepreneurship $\rightarrow$ Interest in Entrepreneurship & 9,660 & Significant \\
\hline $\begin{array}{l}\text { Entrepreneurial Self Efficacy } \rightarrow \text { Attitudes Towards Entrepreneurship } \\
\rightarrow \text { Interest in Entrepreneurship }\end{array}$ & 4,540 & Significant \\
\hline
\end{tabular}

Source: Results of data processing with PLS 3

The T-statistical significance value in table 4.3 shows that relationship between variables in this research model is proven to be significant with a positive relationship. Based on table 4.3, relationship between variables can be explained as follows:

1. Entrepreneurial self-efficacy has a positive and significant effect on entrepreneurial interest.

2. Entrepreneurial self-efficacy has a positive and significant effect on attitudes towards entrepreneurship.

3. Attitudes towards entrepreneurship have a positive effect on interest in entrepreneurship 


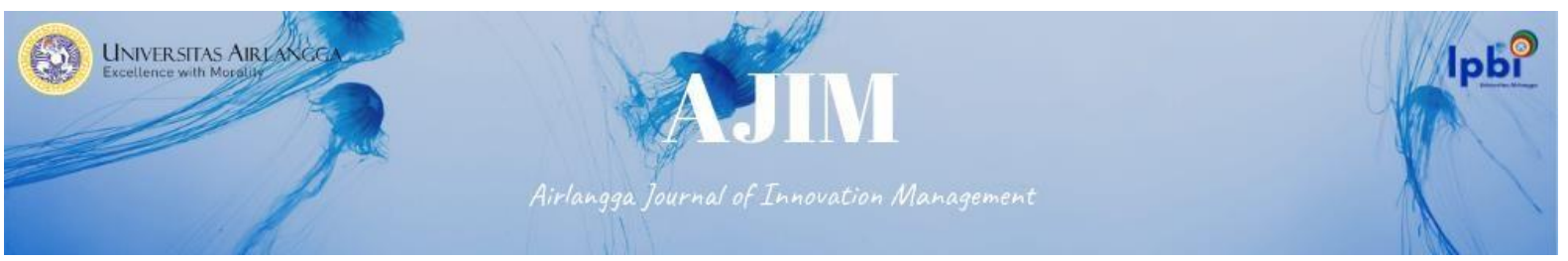

4. Entrepreneurial self-efficacy has a positive effect on interest in entrepreneurship through attitudes towards entrepreneurship.

The first hypothesis of this study which states that there is a positive influence of entrepreneurial self-efficacy on entrepreneurial interest has been proven ( $\mathrm{T}$-statistic $=3.859$ ). The second hypothesis in this study which states that there is a mediating role of attitudes towards entrepreneurship on the positive influence relationship between entrepreneurial self-efficacy and interest in entrepreneurship also proved significant $(\mathrm{T}$-statistic $=4.540)$. The mediating role of attitudes towards entrepreneurship is classified as partial mediation, because direct influence of entrepreneurial self-efficacy on entrepreneurial interest has also been shown to be significant.

Results of data processing of this study prove that entrepreneurial self-efficacy has a positive effect on interest in entrepreneurship. These result means that having strong self-confidence related to abilities and skills in forming and managing a business is able to increase interest in starting a business in Informatics Engineering student semester 5 and 7. Self-efficacy is level of individual confidence in abilities and skills to be able to achieve success in doing certain specific things (Bandura, 1977). In this study, self-efficacy studied was entrepreneurial self-efficacy. Based on results of respondents' answers, it is known that level of entrepreneurial self-efficacy is high (mean = 3.77). The high level of entrepreneurial self-efficacy is an indication that 5th and 7th semesters of IE FST USD students have strong self-confidence in their abilities and skills to establish and manage a business. The entrepreneurial interest of IE FST USD students in semester 5 and 7 is also high (mean $=3.92$ ). The average value of questionnaire responses in same high category indicates that entrepreneurial selfefficacy is able to positively influence entrepreneurial interest. The results of this study which prove that entrepreneurial interest is positively influenced by entrepreneurial self-efficacy are in line with various previous studies, namely research by Wilson et al. (2007) and Tsai et al. (2016) which has proven the positive influence of entrepreneurial self-efficacy on entrepreneurial interest.

Based on the results of data processing, attitudes towards entrepreneurship have been shown to play a significant role in positive relationship between entrepreneurial self-efficacy and entrepreneurial interest so that second hypothesis in this study is accepted. The mediating role of attitudes towards entrepreneurship is in accordance with mediation requirements where relationship between independent variable on mediation must be proven significant and relationship between mediating variable and dependent variable is also proven to be significant (Baron and Kenny, 1986). The meaning of these results is that having strong self-confidence regarding ability and skills to form and manage a business can increase interest in entrepreneurship in IE FST USD student semester 5 and 7 through a positive attitude towards entrepreneurship.

Attitude towards entrepreneurship is a positive or negative assessment or perception related to an individual's career choice as an entrepreneur (Liñán and Chen, 2009). Based on results of respondents' answers, it is known that students' positive attitude towards entrepreneurship is high (mean = 4.03). A positive attitude towards entrepreneurship which is classified as high means that IE FST USD students in semesters 5 and 7 have a positive perception of entrepreneurship as a career choice. Level of entrepreneurial self-efficacy and entrepreneurial interest of IE FST USD students in semester 5 and 7 is also high with an average response value of 3.78 and 3.92, respectively. These results can be interpreted that high level of entrepreneurial self-efficacy is able to form positive perceptions related to career choice as an entrepreneur so that it can encourage a strong interest in entrepreneurship.

The results of this study are in line with previous research by Tsai et al. (2016), Blasco et al. (2018), and Shahab et al. (2019) which has proven that mediating role of attitudes towards 


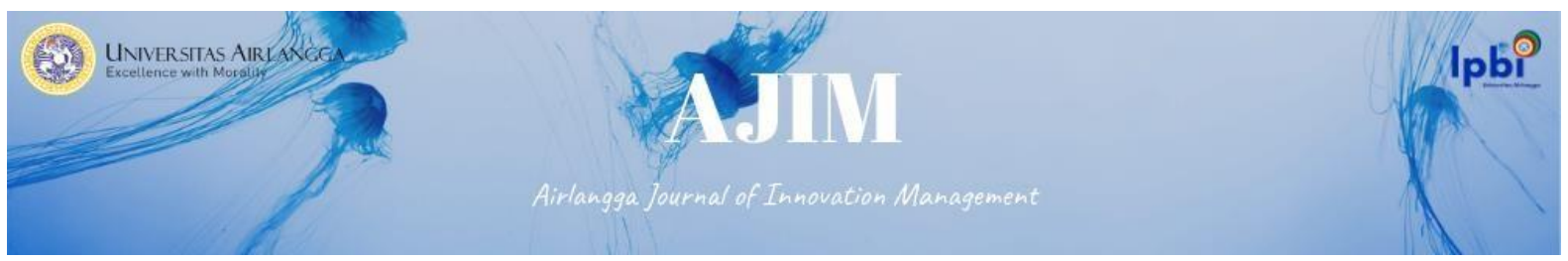

entrepreneurship on positive influence of entrepreneurial self-efficacy on entrepreneurial interest. Selfefficacy is a motivating factor so that it has ability to influence a person's attitudes, behavior, and actions (Bandura, 1997). Confidence in abilities and skills in starting a business can motivate a person to have a positive attitude towards entrepreneurship. Individuals' high level of confidence in their capabilities and talents fosters confidence that they can start a business. This belief ultimately motivates and encourages one's behavior and attitudes towards entrepreneurial activity (Shahab et al., 2019).

\section{Conclusion}

Based on results of data analysis and processing, as well as through hypothesis testing based on research objectives, researchers obtained two conclusions. The first conclusion is that entrepreneurial self-efficacy has a positive effect on entrepreneurial interest. The second conclusion is that attitudes towards entrepreneurship act as a mediator of positive influence of entrepreneurial self-efficacy on entrepreneurial interest. Both hypotheses in this study were accepted. Another conclusion that can be drawn from research result is that entrepreneurial self-efficacy plays a positive role in formation of interest or positive attitude towards entrepreneurship. Then, a positive attitude towards entrepreneurship is able to form an interest in entrepreneurship.

The implication related to results of this study is that high interest in entrepreneurship is formed because of a strong belief in individual abilities and skills in various things needed to manage a business. This strong belief can be created and enhanced through support in the form of debriefing and training related to entrepreneurship that is relevant to current situation, for example training with theme of digital entrepreneurship. The many opportunities to attend seminars, trainings, and briefings in an organized manner are expected to be able to form a positive attitude and interest in entrepreneurship. Suggestions for further research is to involve other motivational variables that have potential to encourage high interest in entrepreneurship. Research on motivational factors for a targeted behavior is certainly in accordance with scope of Human Resource Management studies where management of human or employee is an important issue.

\section{Reference}

Ajzen, I. (1991). The theory of planned behavior. Organizational Behavior and Human Decision Processes, 50(2), 179-211. https://doi.org/10.1016/0749-5978(91)90020-T

Badan Pusat Statistik (BPS). (2020). Pengangguran terbuka menurut pendidikan tertinggi yang ditamatkan. Https:/Www.Bps.Go.Id/Link Tabel Statis/View/Id/972. https://www.bps.go.id/statictable/2009/04/16/972/pengangguran-terbuka-menurut-pendidikantertinggi-yang-ditamatkan-1986---2020

Badan Pusat Statistik (BPS). (2021). Hasil Sensus Penduduk 2020. https://www.bps.go.id/pressrelease/2021/01/21/1854/hasil-sensus-penduduk-2020.html

Bandura, A. (1977). Self-efficacy: toward a unifying theory of behavioral change. Psychological Review, 87(2), 191-215.

Bandura, A. (1997). Self-Efficacy: The Exercise of Control. W. H. Freeman and Company.

BarNir, A., Watson, W. E., \& Hutchins, H. M. (2011). Mediation and Moderated Mediation in the Relationship Among Role Models, Self-Efficacy, Entrepreneurial Career Intention, and Gender. Journal of Applied Social Psychology, 41(2), 270-297. https://doi.org/10.1111/j.15591816.2010.00713.x 


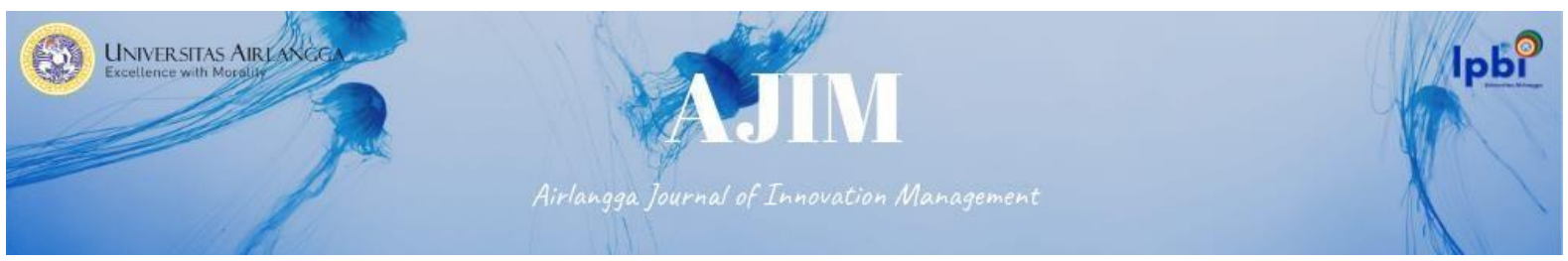

Baron, R. M., Kenny, D. A. (1986). Moderator-Mediator Variables Distinction in Social Psychological Research: Conceptual, Strategic, and Statistical Considerations. Journal of Personality and Social Psychology, 51(6), 1173-1182.

De Noble, A. F., Jung, D., Ehrlich, S. B. (1999). Entrepreneurial self-efficacy: The development of a measure and its relation to entrepreneurial action (R. et Al. (ed.)). Babson College.

Fayolle, A., \& Liñán, F. (2014). The future of research on entrepreneurial intentions. Journal of Business Research, 67(5), 663-666. https://doi.org/10.1016/j.jbusres.2013.11.024

Guerrero, M., Rialp, J., \& Urbano, D. (2008). The impact of desirability and feasibility on entrepreneurial intentions: A structural equation model. International Entrepreneurship and Management Journal, 4(1), 35-50. https://doi.org/10.1007/s11365-006-0032-x

Hair, J. F., Sarstedt, M., Hopkins, L., \& Kuppelwieser, V. G. (2014). Partial least squares structural equation modeling (PLS-SEM): An emerging tool in business research. European Business Review, 26(2), 106-121. https://doi.org/10.1108/EBR-10-2013-0128

Henseler, J., Ringle, C. M., \& Sinkovics, R. R. (2009). The use of partial least squares path modeling in international marketing. Advances in International Marketing, 20(May 2014), 277-319. https://doi.org/10.1108/S1474-7979(2009)0000020014

Kautonen, T., van Gelderen, M., \& Tornikoski, E. T. (2013). Predicting entrepreneurial behaviour: A test of the theory of planned behaviour. Applied Economics, 45(6), 697-707. https://doi.org/10.1080/00036846.2011.610750

KOMINFO. (2020). Pulihkan Ekonomi Nasional, Tumbuhkan Jiwa Kewirausahaan pada Generasi Muda. https://www.kominfo.go.id/content/detail/30271/pulihkan-ekonomi-nasional-tumbuhkanjiwa-kewirausahaan-pada-generasi-muda/0/berita

Liñán, F., Chen, Y. W. (2009). Development and Cross-Cultural Application of a Specific Instrument to Measure Entrepreneurial Intentions. Entrepreneurship Theory and Practice, 33(3), 593-617.

Liñán, F. (2008). Skill and value perceptions: How do they affect entrepreneurial intentions? International Entrepreneurship and Management Journal, 4(3), 257-272. https://doi.org/10.1007/s1 1365-008-0093-0

Liñán, F., Rodríguez-Cohard, J. C., \& Rueda-Cantuche, J. M. (2011). Factors affecting entrepreneurial intention levels: A role for education. International Entrepreneurship and Management Journal, 7(2), 195-218. https://doi.org/10.1007/s11365-010-0154-z

Palamida, E. (2016). Determinants of entrepreneurial intentions: The interrelated role of background, situational and psychological factors. Doctoral Dissertation, May. https://theses.ncl.ac.uk/dspace/bitstream/10443/3299/1/Palamida\%2C E 2016.pdf\%0Ahttp://libproxy.library.wmich.edu/login?url=https://search.proquest.com/docview/ 1913433098?accountid=15099\%0Ahttp://primopmtna01.hosted.exlibrisgroup.com/openurl/01WMU/01WMU_

Parvaneh Gelard. (2011). Impact of some contextual factors on entrepreneurial intention of university students. African Journal of Business Management, 5(26), 10707-10717. https://doi.org/10.5897/ajbm10.891

Rosique-Blasco, M., Madrid-Guijarro, A., \& García-Pérez-de-Lema, D. (2018). The effects of personal 


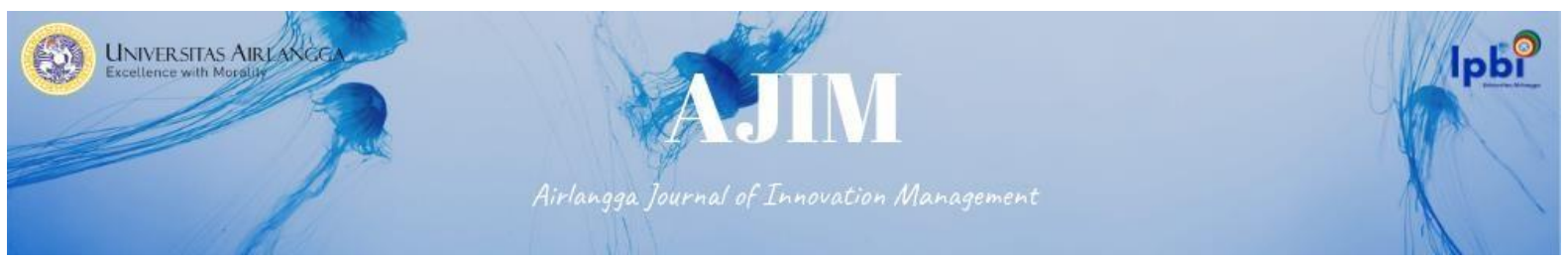

abilities and self-efficacy on entrepreneurial intentions. International Entrepreneurship and Management Journal, 14(4), 1025-1052. https://doi.org/10.1007/s11365-017-0469-0

Sánchez, J. C. (2011). University training for entrepreneurial competencies: Its impact on intention of venture creation. International Entrepreneurship and Management Journal, 7, 239-254.

Shahab, Y., Chengang, Y., Arbizu, A. D., \& Haider, M. J. (2019). Entrepreneurial self-efficacy and intention: do entrepreneurial creativity and education matter? International Journal of Entrepreneurial Behaviour and Research, 25(2), 259-280. https://doi.org/10.1108/IJEBR-122017-0522

Souitaris, V., Zerbinati, S., \& Al-Laham, A. (2007). Do entrepreneurship programmes raise entrepreneurial intention of science and engineering students? The effect of learning, inspiration and resources. Journal of Business Venturing, 22(4), 566-591. https://doi.org/10.1016/j.jbusvent.2006.05.002

Sugiyono. (2017). Metode Penelitian Kuantitatif, Kualitatif dan R\&D. Alfabeta.

Thompson, E. R. (2009). Entrepreneurial Intent : and Development Reliable Metric. Entrepreneurship: Theory and Practice, 33(0), 669-695. http://papers.ssrn.com/sol3/papers.cfm?abstract_id=1396451

Trevelyan, R. (2009). Entrepreneurial Attitudes and Action in New Venture Development. The International Journal of Entrepreneurship and Innovation, 10(1), 21-32. https://doi.org/https://doi.org/10.5367/000000009787414271

Tsai, K. H., Chang, H. C., \& Peng, C. Y. (2016). Refining the linkage between perceived capability and entrepreneurial intention: roles of perceived opportunity, fear of failure, and gender. International Entrepreneurship and Management Journal, 12(4), 1127-1145. https://doi.org/10.1007/s11365016-0383-x

Wilson, F., Kickul, J. R., Marlino, D. (2007). Gender, entrepreneurial self-efficacy, and entrepreneurial career intentions: implications for entrepreneurship education. Entrepreneurship: Theory and Practice, 31(3), 387-406. 